\title{
Testing of Soybean Meal For Genetically MODIFIED ORGANISMS
}

\author{
Vindis, P.; StajnKo, D.; Mursec, B.; Berk, P. \& LAKota, M.
}

Abstract: The purpose of the paper is to show how the GMO (genetically modified organisms) content is tested when the soybean meal is accepted in the feed concentrate factory. After acceptance of the soybean meal the analysis for the protein and moisture content is made. The average monthly sample is sent to an external laboratory for testing for GMO content. According to the regulations the GMO content must not exceed 0,9\% and is determined by the PCR (polymeraze chain reaction) method. Ten analyses for GMO content have been performed by establishing the influence of the origin on the GMO content; the average percentage of GMO in the soybean meal was 0,3\%. In two cases the results of analyses of the soybean meal were negative, which means that the soybean meal did not contain any GMO; in eight cases the test was positive, but none of them exceeded the sill of 0,9\%. The research showed that most soybean meals were genetically modified, but in no case the limit prescribed by the regulations, i.e., 0,9\%, was exceeded.

Key words: soybean meal, GMO, origin, sampling
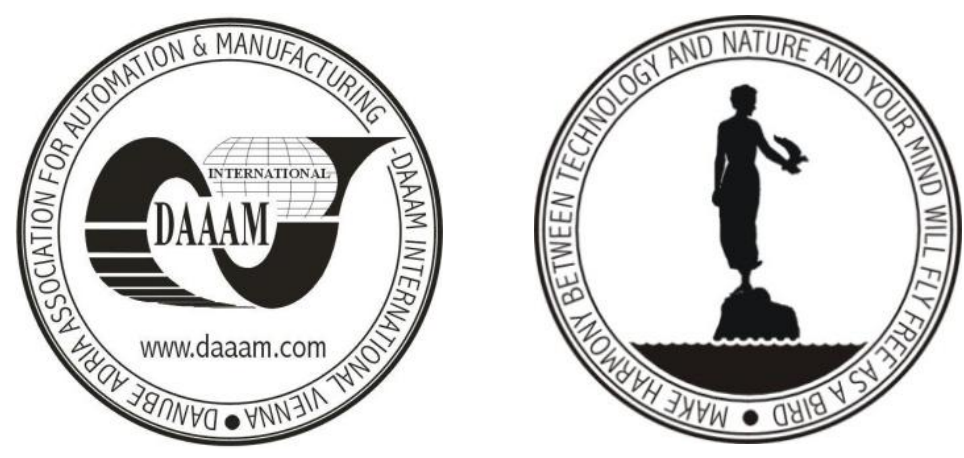

Authors' data: Dr. Vindis, P[eter]; Assoc. Prof. Stajnko, D[enis]; Assoc. Prof. Mursec, B[ogomir]; Berk, P[eter]; Assoc. Prof. Lakota, M[iran], University of Maribor, Faculty of Agriculture and Life Sciences, Pivola 10, SI-2311, Hoce, Slovenia, peter.vindis@uni-mb.si,denis.stajnko@uni-mb.si, bogomir.mursec@unimb.si, peter.berk@uni-mb.si, miran.lakota@uni-mb.si.

This Publication has to be referred as: Vindis, $\mathrm{P}$ [eter]; Stajnko, D[enis]; Mursec, B[ogomir]; Berk, P[eter] \& Lakota, M[iran] (2011). Testing of Soybean Meal for Genetically Modified Organisms, Chapter 12 in DAAAM International Scientific Book 2011, pp. 147-154, B. Katalinic (Ed.), Published by DAAAM International, ISBN 978-3-901509-84-1, ISSN 1726-9687, Vienna, Austria

DOI: $10.2507 /$ daaam.scibook.2011.12 
Vindis, P.; Stajnko, D.; Mursec, B.; Berk, P. \& Lakota, M.: Testing of Soybean Me...

\section{Introduction}

The soybean meal is a highly nutritive product produced by processing highquality peeled soybean grains. It is the most important source of proteins, minerals and vitamins in feeding domestic animals. Worlwide, particularly in the U.S.A as the leading producer of the soybean, most of soybean has already been genetically modified. Genetically modified organism (GMO) is an organism with modified genom to which a new gene has been added. The gene is capable to express an additional protein giving certain new properties, such as tolerating the herbicides or resistance to viruses, antibiotics and insects. At first glance, the resistance to pests, herbicides and illnesses is a very attractive promise, but it does not consider possible harmful effects on the environment and health of humans and does not give overall and correct information about the results of use of GMO (Mariotti et al., 2001). Many countries have prepared the legislation for the use of GMO. In the European Union marking is obligatory for products containing genetically modified maize (Bt maize from Novartis) and for the soybean (RR - soybean from Monsanto), when the precentage of genetically modified organisms is higher than $1 \%$ (Decree (EC) 1829, 2003; Decree (EC) 1830, 2003). Figure 1 shows the soybean prior to processing.

The aim of the study is to show how the GMO (genetically modified organisms) content is tested according the legislation when the soybean meal is accepted in the feed concentrate factory.

Fig. 1. Soybean (Glycine max)

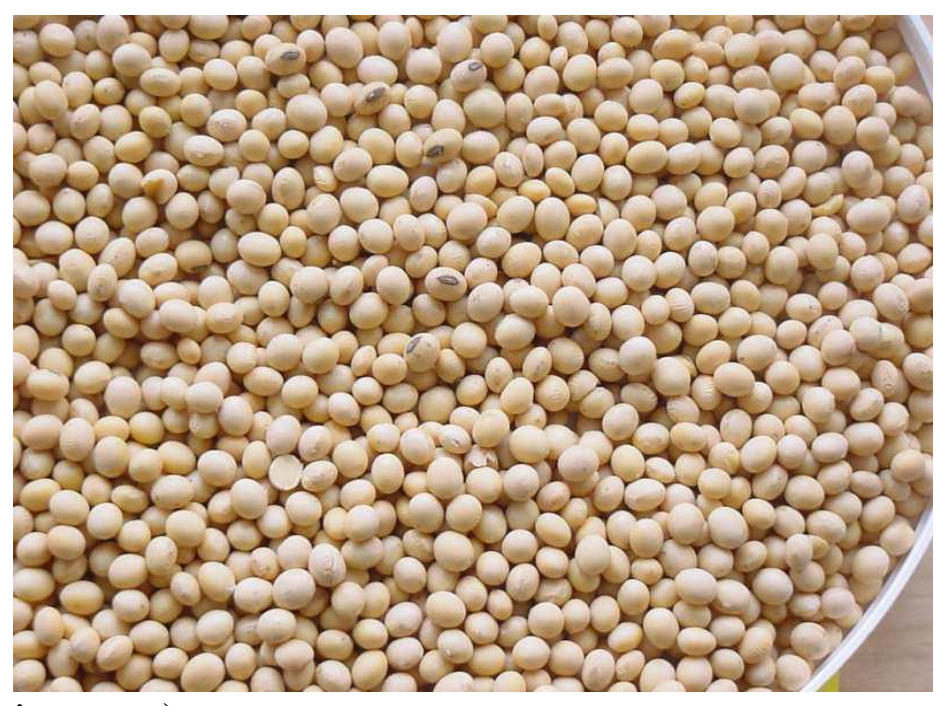

\section{Methodology}

\subsection{Checking of soybean from growing to processing}

Most genetically soybean is produced in the U.S.A and in Brazil from where the ships transport it to the individual countries where it is processed into the soybean meal usable as one of the important components in feeding domestic animals and providing, particulary, the raw proteins (Table 1).

According to the legislation, the soybean must not contain more than $0,9 \%$ of GMO (Gachet et al., 1999; Lin et al., 2001). 


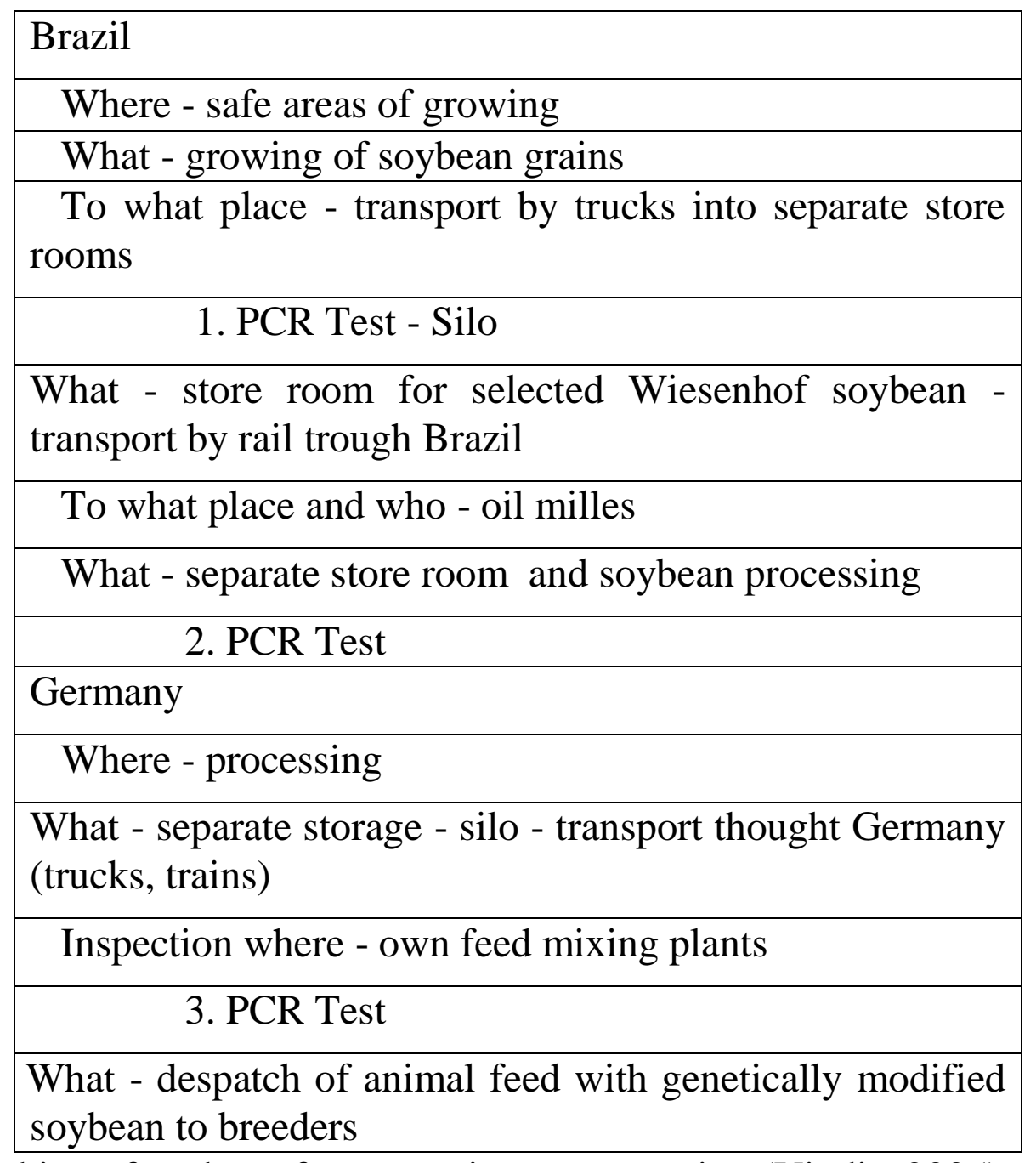

Tab. 1. Checking of soybean from growing to processing (Vindis, 2005)

Since growing of soybean till processing into the soybean meal and other components the soybean is checked for genetically modified organisms with PCR (polymeraze chain reaction) method. Checking is effected in silo, store rooms and in transit. The analysis for the protein and moisture content is made by the use of Inframatic 8620 in feed concentrate factory.

\subsection{Sampling of soybean meal}

The soybean meal was sampled in the same way as the cereals and identical devices and means were used. The sample represented the average composition of the entire quantity of the product from which the sample was taken. It was taken in such a way that each unit of the product had the same chance to be selected. The sample for the analysis of raw materials is the sample obtainted by reducing the total sample and is used for the laboratory analysis. The organoleptic test of the soybean on the transport vehicle is important for the first evaluation of the colour - gloss, odour, health and deterioration or moulding of goods due to the truck or rail wagon roof leakage. Next, the most important part of analysis is effected, namely sampling, since a non - representative sample cannot ensure a realistic estimate and/or analysis of the soybean meal. Figure 2 shows sampling of the soybean meal delivered by a truck. 
Vindis, P.; Stajnko, D.; Mursec, B.; Berk, P. \& Lakota, M.: Testing of Soybean Me...

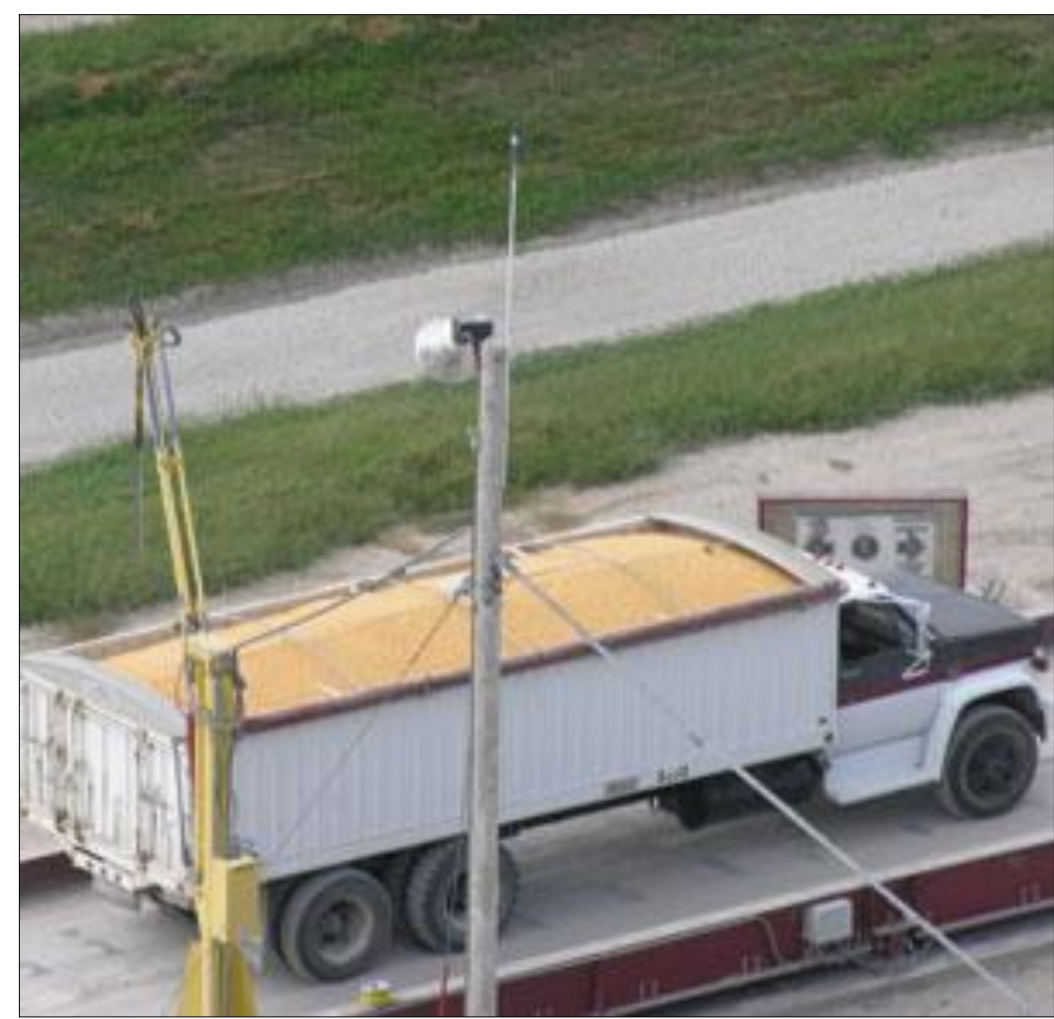

Fig. 2. Sampling of soybean meal

\subsection{Analyzing of soybean meal}

Two suppliers (Agrokor ond Agrograin) from Hungary and Brazil imported the soybean meal $46 \%$ (46\% of proteins in soybean meal). In total, $14.820 .200 \mathrm{~kg}$ of soybean meal arrived in 2005 (Table 2).

The analysis for the presence of GMO in the soybean meal was performed by the National institute for biology in Ljubljana.

\begin{tabular}{|c|c|c|}
\hline Supplier & Weight $(\mathbf{k g})$ & Date of sampling \\
\hline Agrokor - Brazil & 1.630 .200 & $3.1 .-30.1 .2010$ \\
\hline Agrokor - Brazil & 1.300 .400 & $2.2 .-27.2 .2010$ \\
\hline Agrograin - Hungary & 1.140 .600 & $3.3 .-29.3 .2010$ \\
\hline Agrograin - Hungary & 1.210 .300 & $2.4 .-28.4 .2010$ \\
\hline Agrograin - Brazil & 980.300 & $6.6 .-28.7 .2010$ \\
\hline Agrograin - Hungary & 1.170 .400 & $12.6 .-30.7 .2010$ \\
\hline Agrograin - Hungary & 1.380 .200 & $10.8 .-28.8 .2010$ \\
\hline Agrograin - Hungary & 1.050 .200 & $5.9 .-29.9 .2010$ \\
\hline Agrokor - Brazil & 1.505 .300 & $4.11 .-30.11 .2010$ \\
\hline Agrokor - Brazil & 1.602 .600 & $3.12 .-21.12 .2010$ \\
\hline
\end{tabular}

Tab. 2. The soybean meal (46\%) arriving into the feed concentrate factory in 2010, supplied by supplier, date by date of sampling (Vindis, 2005) 


\section{Results with discussion}

\subsection{Results of analysis of soybean meal}

\begin{tabular}{|c|c|c|c|c|}
\hline Origin & Supplier & Result $(\%)$ & Deviations $(\%)$ & Weight $(\mathrm{t})$ \\
\hline Brazil & Agrokor & 0,24 & 0,12 & 1.602 \\
\hline Brazil & Agrokor & 0,34 & 0,14 & 1.505 \\
\hline Hungary & Agrograin & 0,64 & 0,06 & 1.050 \\
\hline Hungary & Agrograin & $>0,1$ & 0 & 1.380 \\
\hline Hungary & Agrograin & 0,42 & 0,18 & 1.170 \\
\hline Brazil & Agrograin & 0 & 0 & 980 \\
\hline Hungary & Agrograin & 0,46 & 0,08 & 1.210 \\
\hline Hungary & Agrograin & 0,42 & 0,12 & 1.140 \\
\hline Hungary & Agrokor & 0,32 & 0,08 & 1.300 \\
\hline Brazil & Agrokor & 0,28 & 0,14 & 1.630 \\
\hline
\end{tabular}

Tab. 3. Results of analysis of soybean meal (46\%), quantities supplied and deviations with respect to origin and supplier of the soybean meal (Vindis, 2005)

On the average, the percentage of GMO in the soybean meal is identical irrespective of the fact by whom and from where it was supplied (Table 3). Only inside the supplier Agrograin of Hungarian origin a slightly greater standard deviation appears involving that the GMO content in the soybean meal is not equalized (Figure 3).

\begin{tabular}{|c|c|c|}
\hline & GSO $(\%)$ & SD \\
\hline Agrokor & 0,30 & 0,04 \\
\hline Agrograin & 0,32 & 0,26 \\
\hline Brazil & 0,22 & 0,15 \\
\hline Hungary & 0,32 & 0,21 \\
\hline
\end{tabular}

Tab. 4. Average values of GMO in soybean meal and standard deviation with respect to supplier and origin (Vindis, 2005)

Table 4 shows the average values of GMO in soybean meal and standard deviation with respect to supplier and origin. In case of soybean meal supplied by Agrokor and soybean meal arriving from Brazil the deviations are equal (Table 5). In case of Agrograin and Hungarian origin the deviations are slightly higher and the relevant standard deviation is slightly higher (Figure 4).

\begin{tabular}{|c|c|c|}
\hline & Deviation $(\%)$ & SD \\
\hline Agrokor & 0,12 & 0,03 \\
\hline Agrograin & 0,19 & 0,31 \\
\hline Brazil & 0,10 & 0,07 \\
\hline Hungary & 0,18 & 0,30 \\
\hline
\end{tabular}

Tab. 5. Average values of deviations and the standard deviation with respect to supplier and origin (Vindis, 2005) 
Vindis, P.; Stajnko, D.; Mursec, B.; Berk, P. \& Lakota, M.: Testing of Soybean Me...

Most soybean meal had been supplied by Agrokor and most of it is of Brazilian origin (Table 6). Average quantities of the soybean meal arriving into the feed concentrate factory with respect to the supplier and origin, are shown (Figure 5).

\begin{tabular}{|c|c|c|}
\hline & Weight $(\mathrm{t})$ & sd \\
\hline Agrokor & 1,51 & 0,15 \\
\hline Agrograin & 1,16 & 0,14 \\
\hline Brazil & 1,43 & 0,30 \\
\hline Hungary & 1,04 & 0,12 \\
\hline
\end{tabular}

Tab. 6. Average quantities of soybean meal in tons and standard deviation with respect to supplier and origin (Vindis, 2005)

Table 7 shows the average values of proteins and moisture in soybean meal with respect to supplier and origin are similar. Proteins and moisture in the soybean meal were determined with Inframatic 8620.

\begin{tabular}{|c|c|c|}
\hline & Proteins (\%) & Moisture (\%) \\
\hline Agrokor & 45,8 & 11,0 \\
\hline Agrograin & 45,9 & 11,4 \\
\hline Brazil & 46,0 & 11,3 \\
\hline Hungary & 45,9 & 11,2 \\
\hline
\end{tabular}

Tab. 7. Average values of proteins and moisture in soybean meal with respect to supplier and origin (Vindis, 2005)

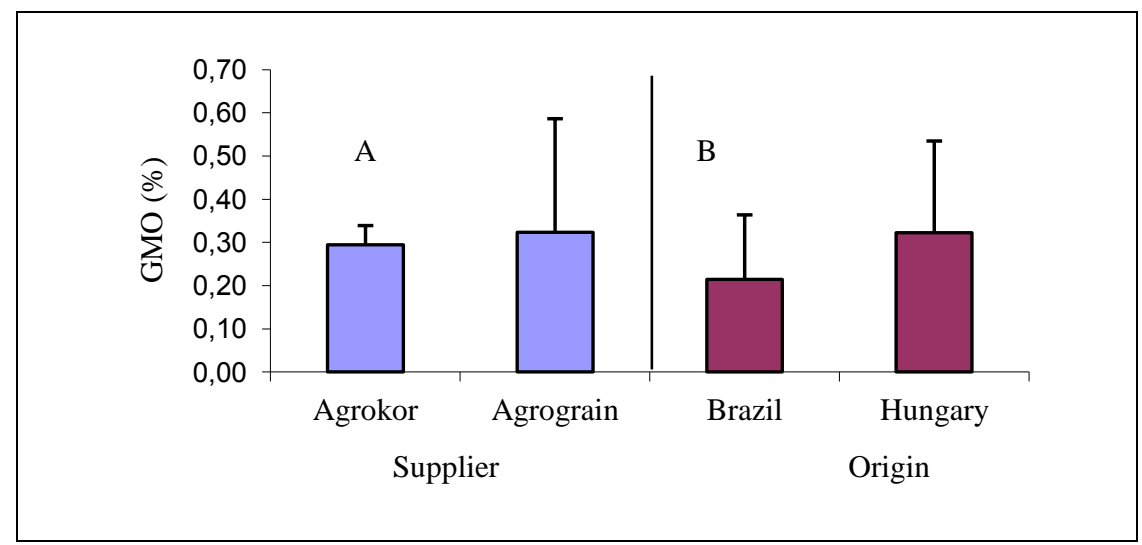

Fig. 3. Average values of GMO in soybean meal and standard deviation with respect to supplier and origin

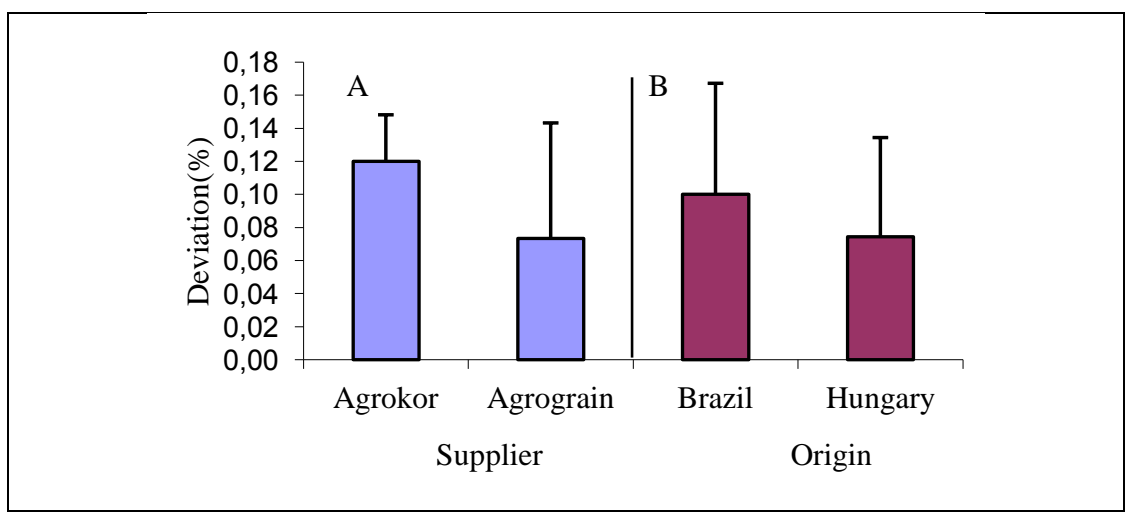

Fig. 4. Average values of deviation and the standard deviation with respect to supplier and origin 


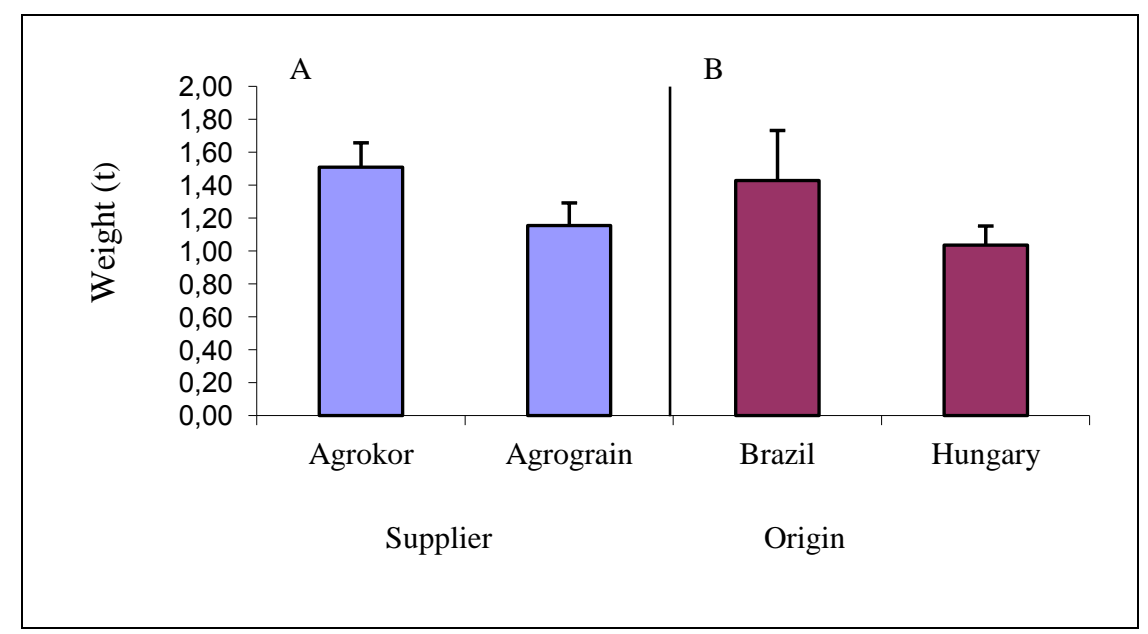

Fig. 5. Average quantities of soybean meal in tons and standard deviation with respect to supplier and origin

There are no statistical differences between the origin and GMO, deviation, quantity, since $\mathrm{P}>0,05$ [19].

The experimental work was performed in the mixing plant of the Poultry breeding company in Ptuj where feed concentrates are mixed for chickens. The average monthly sample was sent to the biological institute in Ljubljana where analysis for the presence of the GMO in raw materials and their products are performed. As such analysis are expensive, ten analysis for the presence of the GMO in the soybean meal were performed in year 2005. In eight cases the result was positive, however, in no case it exceeded the value allowed by the rules and regulations. The soybean meal had been supplied from Brazil and Hungary. On the average, the soybean meal from Hungary contained more GMO than the soybean meal arriving from Brazil. Due to smallness of the sample and as only ten analyses were performed, it cannot be claimed for certain that there is more genetically modified soybean in Hungary then in Brazil.

The GMO become more and more topical, since, for the present, more positive properties than negative ones are known about them. The coming years will show, of course, whether the development went in correct direction or not.

\section{Conclusion}

Sampling of the soybean meal was performed in the same way and with identical devices and means as sampling of cereals. The sample, selected at random, must represent the average composition of the entire quantity of the product. The organoleptic test of the soybean on the transport vehicle is important for the first evalution of its colour, gloss and odour. Reduction of the total sample gives individual samples out of which one is intented to be analyzed and the other to be kept.

According to legal rules and regulations the product, i.e., the soybean meal may contain up to $0,9 \%$ of GMO. The results of analysis of the soybean meal, 
Vindis, P.; Stajnko, D.; Mursec, B.; Berk, P. \& Lakota, M.: Testing of Soybean Me...

performed by the national laboratory in Ljubljana, were negative in two cases; it means that the soybean meal did not contain any GMO. In eight cases the test was positive, but none of them exceeded the $0,9 \%$ sill.

Ten analyses for the presence of the GMO in the soybean meal $(46 \%)$ were performed. Irrespective of the supplier or origin the average percentage of GMO in the soybean meal is approximately the same, i.e., 0,3\%. Only the soybean meal arriving from Brazil had the lowest percentage of GMO, i.e., $0,22 \%$. It means that not the supplier but only the origin have an influence on the percentage of GMO in the soybean meal.

\section{Acknowledgements}

This work has been funded by the Faculty of Agriculture and Life Sciences under the research project with corporation with feed mixture plant.

\section{References}

Decree (EC) No. 1829/2003 of the European parliament and council dated 22. September, 2003 about genetically modified foodstuffs and feed concentrates

Decree (EC) No. 1830/2003 of the European parliament and council dated 22. September, 2003 about traceability and identification of genetically modified organisms and traceability of foodstuffs and feed produces from GMO

Gachet, G. (1999). Detection of geneticaly modified organism (GMOs) by PCR: a brief rewiew of methodologies avaible. Trends in Food Science and Technology, Vol. 5, 380-388, ISSN 0717-3458

Lin, H.; Chang, Y. \& Shih, J.W. (2001). Detection of genetically modified soybeans by PCR method and immunoassay kits. Food Drug Anal, Vol. 9, 160-166, ISSN 1021-9498

Mariotti, E.; Minunni, M. \& Mascini, M. (2001). Surface plasmon resonance for genetically modified organism detection. Anal Chim Acta, Vol. 45, No. 3, 165172, ISSN 0003-2670

Vindis, P. (2005). Analysis of incoming inspection procedure in a feed mixture plant for the detection of genetically modified soybean. Degree, Maribor, 55, ISBN 2240044 